\title{
Influence of mulching and plant spacing on growth and yield of french bean (Phaseolus vulgaris L.)
}

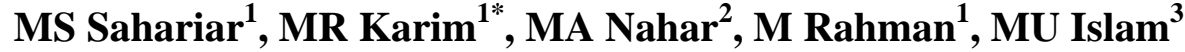 \\ ${ }^{1}$ Department of Horticulture, Bangladesh Agricultural University, Mymensingh-2202; ${ }^{2}$ Department of \\ Biotechnology, EXIM Bank Agricultural University, Bangladesh; ${ }^{3}$ Breeder Seed Production Center, Bangladesh \\ Agricultural Research Institute, Panchagar
}

\begin{abstract}
A field experiment was conducted at the Horticulture Farm of the Department of Horticulture, Bangladesh Agricultural University, Mymensingh to investigatethe effect of mulching and plant spacing on the growth and yield of French bean during the period from November 2014 to January 2015. The experiment consisted of three types of mulchingnamely (i) control (without mulch), (ii) water hyacinth and (iii) black ploythene much and three levels of spacing viz., (i) $30 \mathrm{~cm}$ x $25 \mathrm{~cm}$ (ii) $30 \mathrm{~cm} \mathrm{x} 20 \mathrm{~cm}$ and (iii) $30 \mathrm{~cm} \mathrm{x} 15 \mathrm{~cm}$. The experiment was laid out in randomized complete block design with three replications. Results showed that both mulching and plant spacing significantly influenced the growth and yield components of French bean. Black polythene mulch produced the highest yield (5.82 t/ha) and the lowest yield (4.92 t/ha) was recorded fromno mulch treatment. The maximum yield (6.22 t/ha) was obtained from $30 \mathrm{~cm}$ x $15 \mathrm{~cm}$ plant spacing and the lowest (4.58 t/ha) was obtained with $30 \mathrm{~cm}$ x $25 \mathrm{~cm}$ plant spacing. The combined effects of mulching and plant spacing were statistically significant. The combination of black polythene mulch with $30 \mathrm{~cm} \times 15 \mathrm{~cm}$ spacing gave the highest yield (6.97 t/ha) and the lowest yield (3.94 t/ha) was received from without mulching at spacing of 30 $\mathrm{cm} \times 25 \mathrm{~cm}$ treatment combination. Considering the above findings the black polythene mulch with $30 \mathrm{x} 15 \mathrm{~cm}$ plant spacing may be recommendfor French bean cultivation.
\end{abstract}

Key words: Mulch, polythene sheet, plant spacing, growth, yield, french bean

Progressive Agriculturists. All rights reserve

*Corresponding Author: mrkarim1996@yahoo.com

\section{Introduction}

French bean (Phaseolus vulgaris L.) is one of the most important vegetable crops belongs to the family Leguminosae which originated in the Central and South America (Swiaderet al., 1992). It is extensively grown commercially as well as in the home garden. In Bangladesh, it is known as ',Farashi shim'” (Rashid, 1993)and are mainly used as green vegetables. Its edible immature pods supply protein, carbohydrate, fat, fiber, thiamin, riboflavin, Ca and Fe (Shanmugavelu, 1989) and the seed contains significant amount of thiamine, niacin, folic acid as well as fiber (Rashid, 1999). Major French bean growing districts in Bangladesh areSylhet, Cox's Bazar, Chittagong Hill Tracts. Recently cultivation of French bean is going popularity in Bangladesh mainly because of its demand as a commodity for export. ).

Production of French bean depends on many factors such as quality of seed, variety, fertilizer management, soil moisture, plant spacing and proper management practices. Among them, soil moisture is one of the most important determinants which affect crop growth and yield to a great extent. In 
Bangladesh, French bean is grown in winter season (October-April) when rainfall is scarce. The rainfall pattern during this period is erratic and evapotranspiration is high. As a result, most of the time crop suffers from water stress. Water stress limits French bean growth and development and this stress is one of the reasons of low pod yield of French bean in the country (Mostarinet al., 2005). Therefore, irrigation becomes essential for providing sufficient moisture to the growing crop. Since irrigation water is costly and its judicious application is essential which can be adjusted through standardizing the frequency of irrigation. But where irrigation facilities are not available mulching could be an effective cultural practice to increase soil moisture status thus helps in increase French bean production in a sustainable way. With the help of mulching materials such as crop residues or plant species or polythene sheet soil surface is covered and these are generally practiced in the production of horticultural crops (Wilhoitet al., 1990). Mulching conserves soil moisture and helps to improve soil physical conditions by enhancing biological activity (Mann and Chakor, 1989).

Plant spacing is another factor that affects the yield contributing characters and yield which can be manipulated to maximize yield. With higher spacing vegetative growth enhances because of less competition of nutrients, light, moisture and space but yield potential decreases. Population density modifies the canopy structure and influence light interception, dry matter production and yield of the crop (Parwaret al., 2007; Fukaiet al., 1990). Optimum plant spacing is essential for attaining desired yield because high planting density results in reduction in number of pods per plant and seeds per pods reported by Kuenemanet al. (1979). Optimization of plant density is essential for maximizing yield of good quality French bean and thus the yield potential of French bean could be increased through the suitable combination of mulching and plant spacing.Information regarding mulching and plant spacing on French bean is scanty in scientific literature. The present study, therefore, was undertaken to test the influence of mulching and plant spacing on the growth and yield of French bean.

\section{Materials and Methods}

The research work was conducted at the Horticulture Farm of the Department of Horticulture, Bangladesh Agricultural University, Mymensingh to investigate the effect of mulching and plant spacing on the growth and yield of French bean during the period from November 2014 to January 2015. Plant material of variety BARI Zharshim-1 was used in the study. The seeds were collected from the Vegetable Division of Bangladesh Agricultural Research Institute (BARI), Joydebpur, Gazipur.The two-factor experiment had three different mulching and three different spacingsuch as, Factor A: mulching materials, viz., (i) $\mathrm{M}_{0}$ : No mulch (control), (ii) $\mathrm{M}_{1}$ :water hyacinth mulch, (iii) $\mathrm{M}_{2 \text { : black }}$ polythene mulch; and Factor B: plant spacing namely (i) $\mathrm{S}_{1:} 30 \mathrm{~cm} \times 25 \mathrm{~cm}$, (ii) $\mathrm{S}_{2:} 30 \mathrm{~cm} \times 20 \mathrm{~cm}$, (iii) $\mathrm{S}_{3}$ : $30 \mathrm{~cm} \times 15 \mathrm{~cm}$. The experiment was laid out in randomized complete block design with three replications. There were nine treatment combinations. Each block consisted of nine unit plots. The size of each unit plot was $1.8 \mathrm{~m} \mathrm{x} 1.5 \mathrm{~m}$. Spacing of $1.0 \mathrm{~m} \times 0.5 \mathrm{~m}$ were provided between the blocks and plots, respectively.

At first the land was ploughed with a power tiller and kept open to sunlight. Afterwards the experimental plot was prepared by several ploughing and cross ploughing followed by laddering. The land was fertilized with cow dung $10 \mathrm{t} / \mathrm{ha}$, urea $50 \mathrm{~kg} / \mathrm{ha}$, Triple Super Phosphate (TSP) $160 \mathrm{~kg} / \mathrm{ha}$ and Muritae of Potash (MoP) $160 \mathrm{~kg} / \mathrm{ha}$ (BARC, 2012).The entire amount of well decomposed cow dung,TSP, MoP and half of urea were applied during final land preparation. Rest amount of urea were applied at two installments at 15 and 30 days after sowing. Black polythene and water hyacinth were placed on the respective plots as per treatments before seed sowing. Dried water hyacinth was cut into small pieces and black polythene sheet with small openings were made at proper plant to plant and row to row spacing on the respective plots as per layout. The thickness of mulch maintained for water hyacinth was $8-10 \mathrm{~cm}$. Two seeds were sown in each hill at a depth of 3 cmaccording to treatment When the plants got established, one healthy plant per hill was kept 
and remaining one was plucked.Weeding and mulching were done as and when necessary.

Ten plants were randomly selected from inner side of each plot to avoid border effect. For data collection green pods were harvested at tender stage when they were nearly full with the seeds still small (about onequarter developed) with firm flesh (Swaideret al., 1992). Collected data on yield and yield controlling characters under study statistically analyzed to find out the significance of difference among treatment means. The means for all the treatments were calculated and analysis of variances for most of the characters under consideration was performed by $\mathrm{F}$ variance test. The significance of the difference between pairs of means was evaluated by least significant difference test (LSD) (Gomez and Gomez, 1984).

\section{Results and Discussion}

Plant height: Different mulching materials significantly influenced the plant height. The maximum plant height attained with black polythene mulch $\left(\mathrm{M}_{2}\right)$ was $54.96 \mathrm{~cm}$ at 45 days after sowing

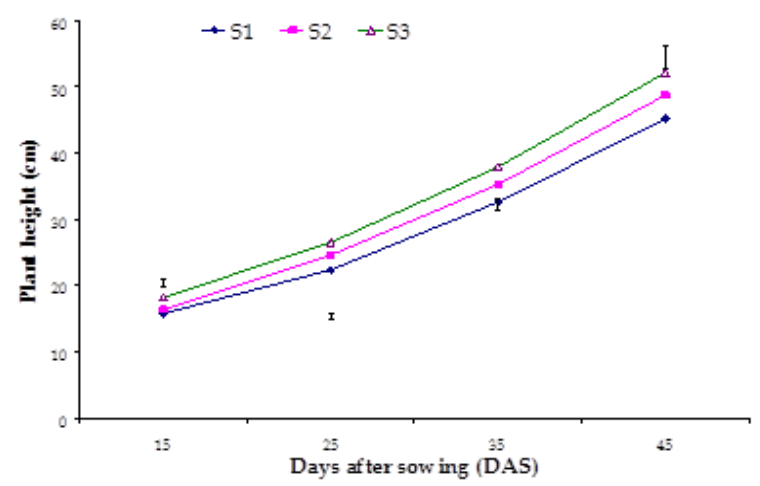

Figure 1. Effect of mulching on the plant height of French bean at different DAS. Vertical bars represent LSD at 0.01 level of probability. $\mathrm{M}_{0}=$ No mulching, $\mathrm{M}_{1}=$ Water hyacinth mulching and $\mathrm{M}_{2}=$ Black polythene mulching.

Number of flowers per plant: The variation in number of flowers produced per plant under different mulch was found statistically significant (Table 2). The maximum number of flowers (22.65) was
(DAS). The minimum plant height $43.26 \mathrm{~cm}$ was found where nomulch was applied (Figure 1). This is due to mulching may be attributed to higher plant height caused by favorable condition utilized by plants as reported by Safiullahet al.,1996.Variation due to the effect of different plant spacing on plant height at 15, 25, 35 and 45 DAS was found significant. The closest plant spacing i.e. $30 \times 15 \mathrm{~cm}$ produced the tallest plant $(52.15 \mathrm{~cm})$ whereas $30 \mathrm{x}$ $25 \mathrm{~cm}$ plant spacing produced the shortest plant $(45.23 \mathrm{~cm})$ (Figure 2). Similar trend was reported by Singh (2011) who reported that at lower spacing produced higher plant height. The interaction effect of mulching and spacing was found to be significant at different days after sowing. The tallest plant $(57.50 \mathrm{~cm})$ was found at 45 DAS from the treatment combination of $\mathrm{M}_{2} \mathrm{~S}_{3}$ (black polythene mulch with shortest spacing of $30 \mathrm{~cm} \mathrm{x} 15 \mathrm{~cm})$ and the smallestplant $(39.67 \mathrm{~cm}$ ) produced by the treatment combination of $\mathrm{M}_{0} \mathrm{~S}_{1}$ (no mulch with highest spacing of $30 \mathrm{~cm}$ x $25 \mathrm{~cm}$ ) (Table 1).

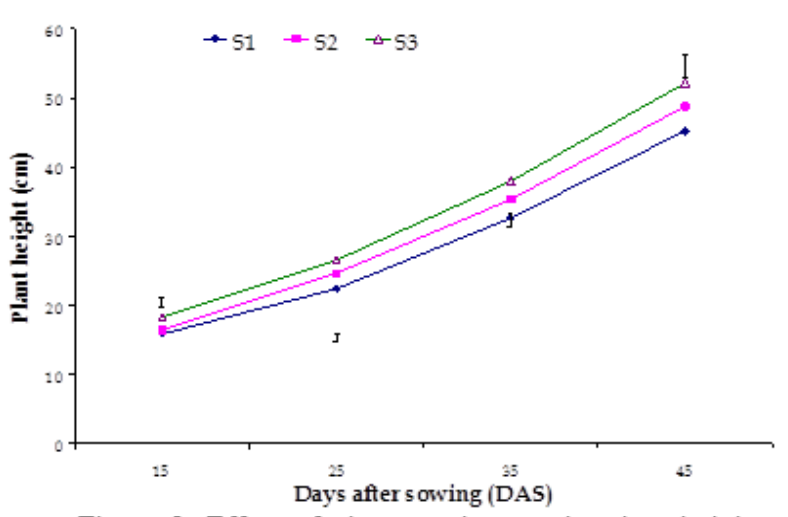

Figure 2. Effect of plant spacing on the plant height of French bean at different DAS. Vertical bars represent LSD at 0.01 level of probability. $S_{1}=30 \mathrm{~cm}$ $\times 25 \mathrm{~cm}, \mathrm{~S}_{2}=30 \mathrm{~cm} \times 20 \mathrm{~cm}$ and $\mathrm{S}_{3}=30 \mathrm{~cm} \times 15 \mathrm{~cm}$.

produced by the plant grown with black polythene followed by water hyacinth mulch which was statistically similar. The minimum number of flowers (17.77) was obtained in no mulch (Table 2). 
Table 1. Combined effect of spacing and mulching on plant height of French bean at different days after sowing

\begin{tabular}{|c|c|c|c|c|}
\hline \multirow[t]{2}{*}{ Treatments } & \multicolumn{4}{|c|}{ Plant height $(\mathrm{cm})$ at } \\
\hline & 15 DAS & 25 DAS & 35 DAS & 45 DAS \\
\hline $\mathrm{M}_{0} \mathrm{~S}_{1}$ & 14.70 & 20.15 & 27.50 & 39.67 \\
\hline $\mathrm{M}_{1} \mathrm{~S}_{1}$ & 15.37 & 22.44 & 32.69 & 43.77 \\
\hline $\mathrm{M}_{2} \mathrm{~S}_{1}$ & 17.42 & 24.55 & 37.69 & 52.25 \\
\hline $\mathrm{M}_{0} \mathrm{~S}_{2}$ & 15.42 & 22.26 & 30.26 & 42.91 \\
\hline $\mathrm{M}_{1} \mathrm{~S}_{2}$ & 16.33 & 24.66 & 35.49 & 48.33 \\
\hline $\mathrm{M}_{2} \mathrm{~S}_{2}$ & 17.50 & 26.93 & 40.18 & 55.14 \\
\hline $\mathrm{M}_{0} \mathrm{~S}_{3}$ & 17.33 & 25.11 & 33.26 & 47.19 \\
\hline $\mathrm{M}_{1} \mathrm{~S}_{3}$ & 17.70 & 26.33 & 38.44 & 51.75 \\
\hline $\mathrm{M}_{2} \mathrm{~S}_{3}$ & 19.70 & 28.14 & 42.15 & 57.50 \\
\hline $\operatorname{LSD}_{(0.05)}$ & 0.295 & 0.219 & 0.465 & 0.787 \\
\hline $\operatorname{LSD}_{(0.01)}$ & 0.406 & 0.302 & 0.640 & 1.082 \\
\hline $\begin{array}{c}\text { Level of } \\
\text { significance }\end{array}$ & $* *$ & $* *$ & ** & ** \\
\hline \multicolumn{5}{|c|}{$\begin{array}{l}M_{0}, M_{1} \text { and } M_{2} \text { indicate no mulching (control), water hyacinth mulching and black polythene mulching, } \\
\text { respectively; } S_{1}, S_{2} \text { and } S_{3} \text { indicate at a spacing of } 30 \mathrm{~cm} \text { x } 25 \mathrm{~cm}, \quad 30 \mathrm{~cm} \text { x } 20 \mathrm{~cm} \text { and } 30 \mathrm{~cm} \text { x } 15 \mathrm{~cm}, \\
\text { respectively; ** indicates significant at } 1 \% \text { level of probability. }\end{array}$} \\
\hline
\end{tabular}

Plant spacing had significant effect on number of flowers per plant. The highest number of flowers (22.44) per plant was obtained from plants sown at the closest spacing of $30 \mathrm{~cm} \times 15 \mathrm{~cm}$ which was similar to $30 \times 20$ cmand the lowest number of flowers (18.47) per plant was produced at spacing of 30 x $25 \mathrm{~cm}$ (Table 3).

The combined effect of different mulching and spacing was significantly influenced the number of flowers per plant (Table 4). The highest number of flowers (25.14) was observed from the treatment combination $\mathrm{M}_{2} \mathrm{~S}_{3}$ (black polythene mulch with closest spacing of $30 \mathrm{~cm} \times 15 \mathrm{~cm}$ ) and the lowest (16.55) was found in $\mathrm{M}_{0} \mathrm{~S}_{1}$ (no mulch with wider spacing of $30 \mathrm{~cm} \times 25 \mathrm{~cm}$ ) treatment combination (Table 4).

Table 2. Main effect of mulching on yield contributing characters and yield of French bean

\begin{tabular}{|c|c|c|c|c|c|c|c|}
\hline Mulching & $\begin{array}{c}\text { Number. } \\
\text { of flowers } \\
\text { plant }^{-1}\end{array}$ & $\begin{array}{l}\text { Number of } \\
\text { pod plant }^{-1}\end{array}$ & $\begin{array}{l}\text { Length of } \\
\text { pod }(\mathrm{cm})\end{array}$ & $\begin{array}{c}\text { Diameter of } \\
\text { pod }(\mathrm{cm})\end{array}$ & $\begin{array}{l}\text { Number. of } \\
\text { seeds pod }{ }^{-1}\end{array}$ & $\begin{array}{c}\text { Fresh pod } \\
\text { weight } \\
\text { plant }^{-1}\end{array}$ & $\begin{array}{l}\text { Fresh pod } \\
\text { yield }\left(t \mathrm{ha}^{-1}\right)\end{array}$ \\
\hline $\mathrm{M}_{0}$ & 17.77 & 15.47 & 11.40 & 1.09 & 4.65 & 53.81 & 4.92 \\
\hline $\mathrm{M}_{1}$ & 20.28 & 16.48 & 12.39 & 1.17 & 4.90 & 56.83 & 5.23 \\
\hline $\mathrm{M}_{2}$ & 22.65 & 18.70 & 13.45 & 1.22 & 5.67 & 58.65 & 5.82 \\
\hline $\mathrm{LSD}_{0.05}$ & 0.210 & 0.253 & 0.176 & 0.110 & 0.100 & 0.313 & 0.200 \\
\hline $\mathrm{LSD}_{0.01}$ & 0.290 & 0.350 & 0.243 & 0.151 & 0.138 & 0.433 & 0.276 \\
\hline $\begin{array}{c}\text { Level of } \\
\text { significance }\end{array}$ & $* *$ & $* *$ & $* *$ & $* *$ & $* *$ & $* *$ & $* *$ \\
\hline
\end{tabular}


Number of pods per plant: There was a marked influence due to the effect of different mulches on the number of pods per plant (Table 2). Higher number of pods per plant (18.70) was obtained from black polythene mulch on the other hand in case of the plant grown with no mulch treatment had lower number of pods (15.47) per plant.

The on main effect of plant spacing on the number of pods have been presented in (Table 3). The highest number of pods per plant was obtained (18.02) in closest spacing of $(30 \mathrm{~cm} \times 15 \mathrm{~cm})$ used and the lowest number of pods per plant was found (15.60) in the widest spacing of $(30 \mathrm{~cm} \times 25 \mathrm{~cm})$.

The combined effect of different mulch and spacing was significantly influenced on the number of pods per plant (Table 4). However numerically the highest number of pods (20.14) was observed from the treatment combination $\mathrm{M}_{2} \mathrm{~S}_{3}$ (black polythene mulch with closest spacing of $30 \mathrm{~cm} \times 15 \mathrm{~cm}$ ) and the lowest number of pods (14.20) was found in $\mathrm{M}_{0} \mathrm{~S}_{1}$ (no mulch with wider spacing of $30 \mathrm{cmx} 25 \mathrm{~cm}$ ) treatment combination.
Length of pod: The length of pod was influenced significantly with the different mulching materials used. The longest pod $(13.54 \mathrm{~cm})$ was obtained from $\mathrm{M}_{2}$ (black polythene mulch). While the shortest pod $(11.40 \mathrm{~cm})$ was found from no mulch treatment (Table 2).The results on main effect of plant spacing on the number of pods have been presented in (Table 3 ). The highest number of pods per plant was obtained $(13.54 \mathrm{~cm})$ in closest spacing of $(30 \times 15$ $\mathrm{cm}$ ) and the lowest number of pods per plant was found $(11.42 \mathrm{~cm})$ in the widest spacing $(30 \mathrm{~cm} \times 25$ $\mathrm{cm})$.

The combined effect of different mulch and spacing significantly influenced the length of pods per plant (Table 4). However, the longestlength of pods (14.63 $\mathrm{cm})$ was observed from the treatment combination $\mathrm{M}_{2} \mathrm{~S}_{3}$ (black polythene mulch with closest spacing of $30 \mathrm{~cm} \times 15 \mathrm{~cm})$ and the lowest length of pods (10.11 $\mathrm{cm}$ ) was found in $\mathrm{S}_{1} \mathrm{M}_{0}$ (no mulch with wider spacing of $30 \mathrm{~cm} \times 25 \mathrm{~cm}$ ) treatment combination (Table 4).

Table 3. Main effect of spacing on yield contributing characters and yield of French bean

\begin{tabular}{|c|c|c|c|c|c|c|c|}
\hline Spacing & $\begin{array}{c}\text { No. of } \\
\text { flowers } \\
\text { plant }^{-1}\end{array}$ & $\begin{array}{l}\text { Number } \\
\text { of pod } \\
\text { plant }^{-1}\end{array}$ & $\begin{array}{l}\text { Length of } \\
\text { pod }(\mathrm{cm})\end{array}$ & $\begin{array}{l}\text { Diameter } \\
\text { of pod }(\mathrm{cm})\end{array}$ & $\begin{array}{l}\text { No. of } \\
\text { seeds } \\
\text { pod }^{-1}\end{array}$ & $\begin{array}{c}\text { Fresh pod } \\
\text { weight(gm) } \\
\text { plant }^{-1}\end{array}$ & $\begin{array}{l}\text { Fresh pod } \\
\text { yield }\left(\mathrm{t} \mathrm{ha}^{-1}\right)\end{array}$ \\
\hline $\mathrm{S}_{1}$ & \multirow{6}{*}{$\begin{array}{c}\text { add } \\
\text { missing } \\
\text { data }\end{array}$} & 15.60 & 11.42 & 1.08 & 4.72 & 54.69 & 4.58 \\
\hline $\mathrm{S}_{2}$ & & 17.03 & 12.28 & 1.16 & 4.97 & 56.20 & 5.17 \\
\hline $\mathrm{S}_{3}$ & & 18.02 & 13.54 & 1.23 & 5.52 & 58.40 & 6.22 \\
\hline $\mathrm{LSD}_{0.05}$ & & 0.253 & 0.176 & 0.110 & 0.100 & 0.313 & 0.200 \\
\hline $\operatorname{LSD}_{0.01}$ & & 0.350 & 0.243 & 0.151 & 0.138 & 0.433 & 0.276 \\
\hline $\begin{array}{c}\text { Level of } \\
\text { significance }\end{array}$ & & $* *$ & $* *$ & $* *$ & $* *$ & $* *$ & $* *$ \\
\hline
\end{tabular}

Diameter of green pod: Mulching had significant influence on diameter of green pod. The thickest $(1.22 \mathrm{~cm})$ pod was obtained in plants grown with black polythene and lowest diameter $(1.09 \mathrm{~cm})$ was found at no mulch (Table 2). The results on main effect of plant spacing on the diameter of green pods have been presented in (Table 3). The highest diameter of pods per plant was obtained $(1.23 \mathrm{~cm})$ in closest spacing of $30 \mathrm{~cm} \mathrm{x} 15$ cmand the lowest diameter $(1.08 \mathrm{~cm})$ was found in the widest spacing of $30 \mathrm{~cm}$ x $25 \mathrm{~cm}$.

The combined effect of different mulch and spacing significantly influenced on the diameter of pods per plant (Table 4). The highest diameter of pods (1.30 $\mathrm{cm}$ ) was observed from the treatment combination 
$\mathrm{M}_{2} \mathrm{~S}_{3}$ (black polythene mulch with closest spacing of $30 \mathrm{~cm} \times 15 \mathrm{~cm})$ and the lowest diameter of pods $(1.01 \mathrm{~cm})$ was found in (no mulch with wider spacing of $30 \mathrm{~cm} \times 25 \mathrm{~cm}$ treatment combination.

Number of seeds per pod: There was significant variation among different mulch materials for number of seeds per pod. The maximum number of seeds per pod (5.67) was obtained from plants grown with $\left(\mathrm{M}_{2}\right)$ black polythene mulch (Table 2). The minimum number of seeds per pod (4.65) was found from plant grown with no mulch $\left(\mathrm{M}_{0}\right)$.

There was significant variation among different plant spacing for number of seeds per pod. There was an increasing trend in number of seeds per pod with the decrease in spacing (Table 3 ). The maximum number of seeds per pod (5.52) was obtained in pods from crops sown at closest spacing of $(30 \mathrm{~cm} \times 15 \mathrm{~cm})$. The minimum number of seeds per pod (4.72) was found in pods from crops sown at the widest spacing of $(30 \mathrm{~cm} \times 25 \mathrm{~cm})$.
The combined effect of mulching and spacing had significant influenced for the number of seeds per pod (Table 4). The highest number of seeds per pod (6.25) was found from the treatment combination of $\mathrm{M}_{2} \mathrm{~S}_{3}$ (black polythene mulch with closest spacing of $30 \mathrm{~cm} \times 15 \mathrm{~cm}$ ). The lowest number of seeds per pod (4.25) was obtained from the treatment combination of $\mathrm{M}_{0} \mathrm{~S}_{1}$ where no mulch and widest spacing of 30 $\mathrm{cm} \times 25 \mathrm{~cm}$ were used.

Fresh weight of pod per plant: The fresh weight of pod was influenced significantly due to different mulching treatment (Table 2). The highest fresh weight of pod per plant (58.65 g) was produced by the black polythene mulch treatments and the lowest $(53.81 \mathrm{~g})$ was found from no mulch material applied.

Significant variation was observed in respect of fresh weight of pod per plant due to different plant spacing (Table 3). The maximum weight of fresh green pod (58.40 g) was obtained in pods from crops sown at closest spacing of $(30 \mathrm{~cm} \times 15 \mathrm{~cm})$. The

Table 4. Combined effect of spacing on yield contributing characters and yield of French bean

\begin{tabular}{|c|c|c|c|c|c|c|c|}
\hline Treatment & $\begin{array}{l}\text { No. of } \\
\text { flowers } \\
\text { plant }^{-1}\end{array}$ & $\begin{array}{l}\text { Number of } \\
\text { pod plant }^{-1}\end{array}$ & $\begin{array}{l}\text { Length of } \\
\text { green pod } \\
\quad(\mathrm{cm})\end{array}$ & $\begin{array}{l}\text { Diameter } \\
\text { of green } \\
\text { pod }(\mathrm{cm})\end{array}$ & $\begin{array}{l}\text { No. of } \\
\text { seeds } \\
\text { pod }^{-1}\end{array}$ & $\begin{array}{l}\text { Fresh pod } \\
\text { wt. plant }{ }^{-1}\end{array}$ & $\begin{array}{l}\text { Fresh pod } \\
\text { yield (t ha- } \\
1 \text { ) }\end{array}$ \\
\hline $\mathrm{M}_{0} \mathrm{~S}_{1}$ & 16.55 & 14.20 & 10.11 & 1.01 & 4.25 & 51.57 & 3.94 \\
\hline $\mathrm{M}_{1} \mathrm{~S}_{1}$ & 18.67 & 15.33 & 11.67 & 1.08 & 4.67 & 55.17 & 4.81 \\
\hline $\mathrm{M}_{2} \mathrm{~S}_{1}$ & 20.18 & 17.28 & 12.47 & 1.16 & 5.25 & 57.33 & 5.01 \\
\hline $\mathrm{M}_{0} \mathrm{~S}_{2}$ & 17.29 & 15.89 & 11.50 & 1.10 & 4.60 & 53.40 & 4.90 \\
\hline $\mathrm{M}_{1} \mathrm{~S}_{2}$ & 19.47 & 16.50 & 12.09 & 1.17 & 4.80 & 56.77 & 5.13 \\
\hline $\mathrm{M}_{2} \mathrm{~S}_{2}$ & 22.63 & 18.69 & 13.24 & 1.21 & 5.50 & 58.44 & 5.50 \\
\hline $\mathrm{M}_{0} \mathrm{~S}_{3}$ & 19.48 & 16.33 & 12.59 & 1.15 & 5.10 & 56.47 & 5.94 \\
\hline $\mathrm{M}_{1} \mathrm{~S}_{3}$ & 22.69 & 17.60 & 13.40 & 1.25 & 5.22 & 58.55 & 5.75 \\
\hline $\mathrm{M}_{2} \mathrm{~S}_{3}$ & 25.14 & 20.14 & 14.63 & 1.30 & 6.25 & 60.17 & 6.97 \\
\hline $\mathrm{LSD}_{0.05}$ & 0.364 & 0.439 & 0.305 & 0.190 & 0.173 & 0.543 & 0.347 \\
\hline $\mathrm{LSD}_{0.01}$ & 0.500 & 0.603 & 0.420 & 0.261 & 0.238 & 0.746 & 0.476 \\
\hline $\begin{array}{c}\text { Level of } \\
\text { significance }\end{array}$ & $* *$ & * & $* *$ & $* *$ & * & $* *$ & $* *$ \\
\hline \multicolumn{8}{|c|}{$\begin{array}{l}\mathrm{M}_{0}, \mathrm{M}_{1} \text { and } \mathrm{M}_{2} \text { indicate no mulching (control), water hyacinth mulching and black polythene mulching, } \\
\text { respectively; } \mathrm{S}_{1}, \mathrm{~S}_{2} \text { and } \mathrm{S}_{3} \text { indicate at a spacing of } 30 \mathrm{~cm} \text { x } 25 \mathrm{~cm}, \quad 30 \mathrm{~cm} \times 20 \mathrm{~cm} \text { and } 30 \mathrm{~cm} \times 15 \mathrm{~cm} \text {, } \\
\text { respectively; * and ** indicate significant at } 5 \% \text { and } 1 \% \text { levels of probability, respectively. }\end{array}$} \\
\hline
\end{tabular}

minimum weight of fresh green pod (54.69 g) was found in pods from crops sown at the widest spacing of $(30 \times 25 \mathrm{~cm})$. The interaction effects of mulching and spacing were significant on fresh weight of pod per plant (Table 4). The highest fresh weight of pod per plant $(60.17 \mathrm{~g})$ was found the 
treatment combination $\mathrm{M}_{2} \mathrm{~S}_{3}$ (black polythene mulch with closest spacing of $30 \mathrm{~cm} \mathrm{x} 15 \mathrm{~cm})$. The lowest (51.57 g) was obtained from $\mathrm{M}_{0} \mathrm{~S}_{1}$ (no mulch with wider spacing of $30 \mathrm{~cm} \mathrm{x} 25 \mathrm{~cm}$ ) treatment combination.

Fresh pod yield: The different mulching was found to influence significantly the pod yield per hectare at harvest (Table 2). It is apparent from table that the highest pod yield (5.82 tha ${ }^{-1}$ ) per hectare was found from black polythene mulch $\left(\mathrm{M}_{2}\right)$ and the lowest $\left(4.92\right.$ tha $\left.^{-1}\right)$ per hectare was obtained in no mulch treatment.

Plant spacing had significant influence on fresh pod yield per hectare (Table 3). A wide variation was observed among the different plant spacing. The highest fresh pod yield (6.22 tha $\left.{ }^{-1}\right)$ was obtained from $(30 \mathrm{~cm} \times 15 \mathrm{~cm}$ ) plant spacing. On the other hand, the lowest fresh pod yield $\left(4.58 \mathrm{t} \mathrm{ha}^{-1}\right)$ was found from widest spacing of $(30 \mathrm{~cm} \times 25 \mathrm{~cm})$ (Table 3).

The interaction effects of mulching and spacing had significant effect on fresh pod yield per hectare (Table 4). The highest fresh pod yield $\left(6.97 \mathrm{t} \mathrm{ha}^{-1}\right)$ was found the treatment combination $\mathrm{M}_{2} \mathrm{~S}_{3}$ (black polythene mulch with closest spacing of $30 \mathrm{~cm} \times 15$ $\mathrm{cm})$. The lowest $\left(3.94 \mathrm{t} \mathrm{ha}^{-1}\right)$ was obtained from $\mathrm{M}_{0} \mathrm{~S}_{1}$ (no mulch with wider spacing of $30 \mathrm{~cm} \times 25$ $\mathrm{cm})$ treatment combination.

\section{References}

Anonymous (2001). Hurter promoted export during October-December, 2001 compared with corresponding period last year. Hortex Foundation Newsletter,1(4): 1-4.

BARC (Bangladesh Agricultural Research Council)(2012).Fertilizer Recommendation Guide-2012.Bangladesh Agricultural Research Council.pp. 121.

Fukai SC, Searle H, BaiquniS, Kywe M (1990). Growth and grain yield of contrasting barley cultivars under different plants densities. Field Crop Research,23: 239-254.

Gomez KA, Gomez AA (1984). Statistical Procedures for Agricultural Research. $2^{\text {nd }}$ edn.A
Wiley-Interscience Publication.John Wiley and Sons, New York, Chichester, Brisbane, Toronto, Singapore.pp: 28-192.

Kueneman EA, Sandsted RF, Wallace DH, Bravo A,Wien HC (1979).Effect of plant arrangements and densities on yields of dry beans.Journal of Agronomy,71:419-424.

Mann JS,Chakor JS (1989). Effect of fresh and weed control on rain fed sugarcane Raton. Indian Journal of Agronomy,39(3): 279-282.

Mostarin T, Khatun K, Kabir MH, UddinAFMJ,Zaman SMA (2005). Optimizing the productivity of French bean by appropriate management of nitrogen and mulch practices.International Journal of Sustainable Agricultural Technology,1(2): 20-25.

Parwar SU, KharwadeML,Awari HW (2007). Effect of plant density on vegetative growth and yield performance of different varieties of French bean under irrigated condition.Karnataka Journal of Agricultural Science, 20: 684-685.

Rashid MM (1993).SabjiBiggan (in Bengali). $1^{\text {st }}$ Edition. Bangla Academy, Bangladesh. pp. 387-390.

Rashid MM (1999). SabjiBiggan (in Bengali). $2^{\text {nd }}$ Edition.Rashid publishing House.Dhaka. pp. 396-399.

Safiullah M, AhmedSU,Rahman MH (1996).Effect of mulching on the growth and yield of cabbage.ProgressiveAgriculture, 7(1): 15-19.

Shanmugavelu KG (1989). Production Technology of Vegetable crops.Oxford and IBH publishing Company Private Limited. New Delhi. pp. 446461.

Singh BK, Pathak KA, Verma AK, VermaVK, Deka BC (2011). Effects of vermicompost, fertilizer and mulch on plant growth, nodulation and pod yield of French bean (Phaseolus vulgaris L.). Vegetable Crops Research Bulletin 74: 153-165.

Swiader JM, Ware GW, McCollum JP (1992). Production Vegetables Crops. $4^{\text {th }}$ Edition.Interstate Publishers.Incorporation Danville Illions, United States of America. pp. 223-249.

Wilhoit JH, Morse RD, Vaughan DH (1990). Strip tillage production of summer cabbage using high residue levels. Applied Agricultural Research,5(4): 338- 342. 